\title{
Carbamazepine substitution in severe partial epilepsy: implication of autoinduction of metabolism
}

\author{
Graeme J.A. Macphee and Martin J. Brodie \\ Clinical Pharmacology Unit, University Department of Medicine, Western Infirmary, Glasgow G11 6NT, UK.
}

\begin{abstract}
Summary: Established partial seizures are often refractory to treatment and many patients receive polypharmacy. An attempt was made to improve seizure control with the substitution of carbamazepine (CBZ) for existing treatment in 7 consecutive unremitting cases of partial epilepsy referred by their physicians as 'intractable'. This produced a significant improvement in control of partial $(P<0.02)$ and secondary generalized $(P<0.01)$ seizures, with 5 patients experiencing a $50 \%$ or greater reduction in seizure frequency. A single patient suffered a generalized seizure during the period of changeover. In 3 cases auto-induction of $\mathbf{C B Z}$ metabolism resulted in temporary loss of seizure control which was restored by an increase in dose. A policy of planned substitution of CBZ in partial epilepsy previously regarded as intractable may be successful in selected patients. The possible deleterious effect of $\mathrm{CBZ}$ auto-induction should be anticipated.
\end{abstract}

\section{Introduction}

Partial seizures are more difficult to control than other types of epilepsy in the adult (Reynolds et al., 1983). Many such patients receive two or more drugs (Guelen et al., 1975) without evidence of improved response (Shorvon et al., 1978) but increased potential for toxicity (Reynolds, 1975). They represent a major source of morbidity in the community, and often require multiple resources of medical, psychiatric and social care.

Carbamazepine (CBZ) has been shown to be of value in the reduction of polypharmacy (Maheshwari \& Padmini, 1981) but scrutiny of recent studies suggests this drug may have been overlooked in the approach to poorly controlled epilepsy (Goodridge \& Shorvon, 1983). CBZ and phenytoin (DPH) are considered the first line agents in partial epilepsy (Davidson, 1983) and double-blind clinical trials have not demonstrated important differences in efficacy between them (Simonsen et al., 1976; Troupin et al., 1977; Kosteljanetz et al., 1979; Ramsay et al., 1983). Notably, however, equal numbers of patients have improved control on either agent and therefore therapeutic equivalence between CBZ and DPH cannot be assumed for the individual patient. Accordingly we have introduced the policy of substitution with CBZ for older agents with reduction of polypharmacy in patients who have poorly controlled partial seizures regarded by the referring physician as intractable. Our

Correspondence: M.J. Brodie, M.D., M.R.C.P.

Accepted: 1 April 1985 initial experience with the first 7 consecutive cases is outlined below.

\section{Patients and methods}

Seven patients with severe complex partial epilepsy referred consecutively from clinicians within the Western Infirmary/Gartnavel General Hospital complex were studied. Five patients received DPH alone, one a combination of phenytoin, primidone and sodium valproate and the last phenobarbitone, sodium valproate and low dose CBZ, having previously received DPH. Clinical details and inter-ictal electroencephalogram (EEG) findings are shown in Table I.

Frequency of seizures was assessed in a baseline period (range 4-36 months) when the patient was under regular medical review and following modification of therapy (range 5-18 months), using a monthly seizure frequency chart completed by the patient or his family. Prior to conversion, patients were required to have plasma concentrations of at least one major anticonvulsant in the 'therapeutic' range (Reynolds, 1980). If concentrations of established medication were higher than this, dosage was first reduced to exclude paradoxical seizures prior to introduction of CBZ (Troupin \& Ojemann, 1975).

CBZ was introduced in an initial dosage of $200 \mathrm{mg} \mathrm{b.d}$. and increased as necessary to produce target plasma trough and peak concentrations of $6-10 \mathrm{mg} / 1$ while maintaining existing therapy. Subsequent withdrawal of previous anticonvulsants was 
Table I Clinical details and inter-ictal EEG of 7 patients with partial epilepsy

\begin{tabular}{|c|c|c|c|c|c|c|}
\hline $\begin{array}{l}\text { Case } \\
\text { no. }\end{array}$ & $\operatorname{Sex}$ & $\begin{array}{l}\text { Age } \\
(y)\end{array}$ & Seizure type & $\begin{array}{l}\text { Duration } \\
\quad(y)\end{array}$ & Aetiology & Inter-ictal EEG abnormality \\
\hline 1. & $\mathbf{F}$ & 34 & $\begin{array}{l}\text { Complex partial } \\
\text { Secondary generalized }\end{array}$ & 12 & Perinatal injury & Right temporal theta \\
\hline 2. & $\mathbf{M}$ & 56 & Secondary generalized & 7 & $\begin{array}{l}\text { Sub-arachnoid haemorrhage } \\
\text { Cerebral infarct }\end{array}$ & Right frontal delta \\
\hline 3. & $\mathbf{M}$ & 31 & $\begin{array}{l}\text { Complex partial } \\
\text { Secondary generalized }\end{array}$ & 3 & Cerebral haemorrhage & Right temporal delta \\
\hline 4. & $\mathrm{~F}$ & 30 & $\begin{array}{l}\text { Complex partial } \\
\text { Secondary generalized }\end{array}$ & 26 & $\begin{array}{l}\text { Perinatal injury } \\
\text { Cerebral palsy }\end{array}$ & $\begin{array}{l}\text { Right fronto-temporal } \\
\text { theta }\end{array}$ \\
\hline 5. & $\mathrm{~F}$ & 54 & $\begin{array}{l}\text { Complex partial } \\
\text { Secondary generalized }\end{array}$ & 41 & Cerebral infection & $\begin{array}{l}\text { Left fronto-temporal } \\
\text { theta }\end{array}$ \\
\hline 6. & $\mathbf{M}$ & 29 & $\begin{array}{l}\text { Complex partial } \\
\text { Secondary generalized }\end{array}$ & 8 & ? Perinatal injury & Right temporal delta \\
\hline 7. & $\mathbf{M}$ & 19 & $\begin{array}{l}\text { Complex partial } \\
\text { Secondary generalized }\end{array}$ & 11 & ? Perinatal injury & $\begin{array}{l}\text { Left fronto-temporal } \\
\text { theta and delta }\end{array}$ \\
\hline
\end{tabular}

undertaken in hospital over a period of 7-21 d. If seizures continued, CBZ dosage was increased as necessary to the limit of subjective tolerance, as evidenced by the development of unacceptable sedation, diplopia, nausea or ataxia. Plasma CBZ concentration was monitored but CBZ dosage only altered if seizure frequency increased or toxicity became apparent. Comparison of pre- and post-conversion monthly seizure frequencies was made using Student's $t$ test for paired values.

\section{Results}

Pre- and post-conversion drugs with doses, steadystate concentrations and observation periods are given in Table II. All patients benetfited from the introduc- tion or optimization of CBZ in improved seizure control. Five patients had a $50 \%$ or greater reduction in seizure frequency. Reduction in both secondary generalized seizures $(P<0.01)$ and complex partia $\complement_{5}$ episodes $(P<0.02)$ occurred (Figure 1). Temporari loss of seizure control developed in patients 5, 6 and $7 \overrightarrow{\mathbb{D}}^{+}$ This was accompanied by a fall in circulating steadp state CBZ concentration of $25 \%, 23 \%$ and $30 \%$ respectively, on unaltered dosage. In each case $\frac{8}{0}$ increment in CBZ dose restored the previous levelso and all 3 patients once again became seizure free. problem is illustrated by clinical details from Case 50

\section{Case 5}

This 54 year old unmarried woman was referred in January 1983 . She had suffered from meningitis at ag $\vec{E}$

Table II Pre- and post-conversion drugs, doses, steady state concentrations, and observation periods in 7 patients with sever partial epilepsy

\begin{tabular}{|c|c|c|c|c|c|c|c|c|}
\hline \multirow[b]{2}{*}{$\begin{array}{c}\text { Case } \\
\text { no. }\end{array}$} & \multicolumn{4}{|c|}{ Pre-conversion } & \multicolumn{4}{|c|}{ Post-conversion } \\
\hline & Drug & $\begin{array}{c}\text { Dose } \\
(m g / d)\end{array}$ & $\begin{array}{c}\text { Steady state } \\
\text { concentrations } \\
(\mathrm{mg} / \mathrm{l})\end{array}$ & $\begin{array}{c}\text { Observation } \\
\text { period } \\
\text { (months) }\end{array}$ & Drug & $\begin{array}{c}\text { Dose } \\
(m g / d)\end{array}$ & $\begin{array}{l}\text { Steady state } \\
\text { concentrations } \\
(\mathrm{mg} / \mathrm{l})\end{array}$ & $\begin{array}{c}\text { Observation } \\
\text { period } \\
\text { (months) }\end{array}$ \\
\hline 1 & DPH & 300 & $14.9-16.9$ & 12 & CBZ & 1200 & $3.4-7.7$ & 5 \\
\hline 2 & DPH & 400 & $16-21$ & 4 & CBZ & 800 & $8.5-9.8$ & 8 \\
\hline 3 & DPH & 600 & 48 & 36 & CBZ & 1200 & $10.7-14.5$ & 6 \\
\hline 4 & DPH & 350 & 14 & 5 & CBZ & 1200 & $6.2-11.5$ & 9 \\
\hline 5 & DPH & 350 & $14.2-22$ & 6 & CBZ & 1800 & $9.4-10.3$ & 8 \\
\hline \multirow[t]{3}{*}{6} & PB & 60 & 4.6 & 6 & CBZ & 1800 & $9.4-16.3$ & 6 \\
\hline & VALP & 2000 & 64 & & & & & \\
\hline & CBZ & 400 & 6.7 & & & & & \\
\hline \multirow[t]{4}{*}{7} & DPH & 400 & 11.6 & 6 & CBZ & 1800 & $11.3-16.5$ & 18 \\
\hline & PRIM & 750 & 10.3 (PRIM) & & VALP & 2000 & $37-52$ & \\
\hline & & & 26.1 (PB) & & & & & \\
\hline & VALP & 1800 & 47 & & & & & \\
\hline
\end{tabular}

$\mathrm{CBZ}=$ carbamazepine; $\mathrm{PB}=$ phenobarbitone; $\mathrm{VALP}=$ sodium valproate DPH = phenytoin; $\mathrm{PRIM}=$ primidone. 


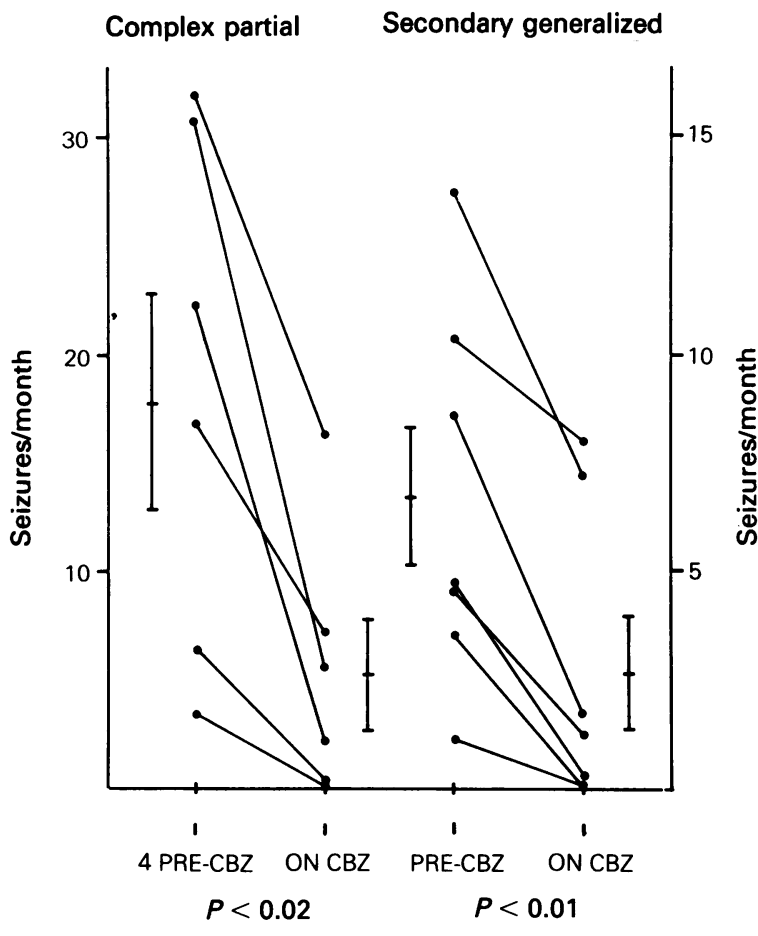

Figure 1 Frequency of partial and secondary generalized seizures per month before and after CBZ therapy in 7 patients with severe partial epilepsy. Statistics were obtained using Student's $t$ test for paired values.

3 , complicated by mild mental retardation and had developed epilepsy 10 y later. In 1981, she became confused and incontinent with frequent falls. Longstanding drug therapy consisted of phenytoin $100 \mathrm{mg} / \mathrm{d}$, primidone 250 q.i.d. and phenobarbitone $90 \mathrm{mg}$ t.i.d. An elevated serum phenobarbitone concentration of $90 \mathrm{mg} / \mathrm{l}$ ('therapeutic' range $10-40 \mathrm{mg} / \mathrm{l}$ ) with low DPH levels encouraged the patient's physician to convert her to DPH monotherapy. Throughout the remainder of 1981 and during the whole of 1982 , however, the patient continued to have frequent partial seizures and several generalized tonic-clonic fits each month despite steady-state DPH concentrations of around $20 \mathrm{mg} / \mathrm{l}$.

On referral to the Clinical Pharmacology Unit in January 1983, CBZ was substituted for DPH over a 21 day period without deterioration in seizure control. Seizure frequency markedly declined thereafter and the patient became seizure free on CBZ $400 \mathrm{mg}$ b.d. In April, partial seizures recurred and the circulating CBZ level was noted to have fallen over the previous 2 months from $10.4 \mathrm{mg} / 1$ to $7.8 \mathrm{mg} / 1$ (Figure 2). The CBZ dosage was increased to $400 \mathrm{mg}$ t.i.d. with restoration of circulating $\mathrm{CBZ}$ concentrations to around
$10 \mathrm{mg} / \mathrm{l}$. The patient remains well and is currently seizure free. As compliance with drug therapy was consistently supervised by her sister, the deterioration in this patient's epilepsy was thought to be a consequence of auto-induction of $\mathrm{CBZ}$ metabolism.

\section{Discussion}

CBZ is an effective anticonvulsant for partial and secondary generalized epilepsy given singly (Cereghino et al., 1974) or in combination (Cereghino et al., 1975). Our preliminary results, using CBZ as an alternative monotherapy or in replacing polypharmacy, are in general agreement with those of Callaghan and his colleagues (1978) who reported a $50 \%$ or greater reduction in seizure frequency in 9 patients of a group of 19 on previous monotherapy or combination therapy. A more recent study evaluated CBZ or DPH substitution in 18 patients treated with 2 or more anticonvulsants (Lesser et al., 1984). Treatment with a single drug was equal or better than polypharmacy but only a few patients became seizurefree. While appreciating that our study group was small, all were 'intractable' cases and 4 had associated neuro-psychiatric handicap in which a poorer prognosis is recognized (Reynolds et al., 1983).

In any policy of substitution and reduction of anticonvulsant polypharmacy there is a risk of exacerbating seizures (Shorvon \& Reynolds, 1979), particularly if barbiturates are to be withdrawn (Fischbacher, 1982). The best approach to transition is poorly defined and in this preliminary study we did not find deterioration of control even over a 1 week period of

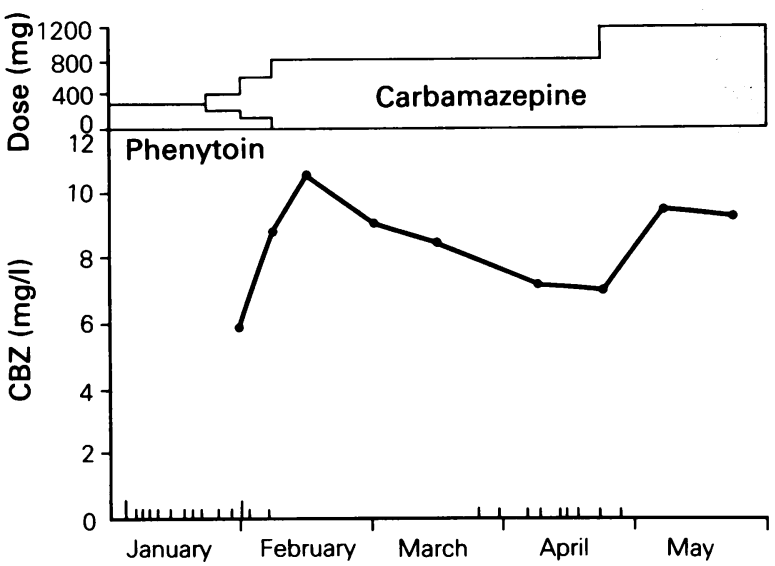

Figure 2 Deteriorating seizure control on fixed dose of carbamazepine (CBZ) with falling plasma concentrations attributable to auto-induction in Case 5. Generalized (longer lines) and partial (shorter lines) seizures are illustrated at the foot. 
withdrawal (Cases 1 and 2). This may reflect a policy of ensuring a 'target' CBZ concentration of between $6-10 \mathrm{mg} / \mathrm{l}$ before reduction of existing therapy. One patient (Case 3) did, however, suffer a generalized convulsion following reduction of DPH concentration from above to within the 'therapeutic' range, a problem previously highlighted (Reynolds et al., 1981).

CBZ characteristically stimulates its own metabolism by auto-induction of hepatic mono-oxygenase enzymes (Eichelbaum et al., 1975) in a dose-dependent manner (Rapeport et al., 1983). This may occur over a period of several weeks following each increment of increased dosage. Cases 5, 6 and 7 illustrated the clinical relevance of this, where falling plasma CBZ concentrations were associated with an increase in seizure frequency. All 3 patients insisted that compliance with drug therapy was perfect and indeed it was supervised throughout by relatives in Case 5 and 6. Minor fluctuations in plasma levels may cause loss of control (Rodin et al., 1974) and if auto-induction is overlooked, a patient may be deemed non-compliant or CBZ may be discontinued or another anticonvulsant added. If reduced plasma concentrations of $\mathrm{CBZ}$ are apparent then adjustment of CBZ dosage should be made before breakthrough seizures develop. Poor compliance may present a similar picture but a brief period of hospital admission for supervision of therapy and plasma concentration monitoring will differentiate these problems.

CBZ therapy may be associated with apparent improvement in mental function and this was reported in Cases 4 and 5. This is consistent with positive psychotropic properties postulated for the drug

\section{References}

CallaghaN, N., O'CAllaghaN, M., DUGGaN, B. \& FEELY, M. (1978). Carbamazepine as a single drug in the treatment of epilepsy. Journal of Neurology, Neurosurgery \& Psychiatry, 41, 907.

CEREGHINO, J.J., BROCK, J.T., VAN METER, J.C., PENRY, J.K., SMITH, L.D. \& WHITE, B.G. (1974). Carbamazepine for epilepsy: a controlled prospective evaluation. Neurology, 24, 401.

CEREGHINO, J.J., BROCK, J.T., VAN METER, J.C., PENRY, J.K., SMITH, L.D. \& WHITE, B.G. (1975). The efficacy of carbamazepine combinations in epilepsy. Clinical Pharmacology \& Therapeutics, 18, 733.

DALBY, M.A. (1975). Behavioural effects of carbamazepine. In Advances in Neurology Penry, J.K. \& Daly, D.D. (eds). Vol 11, Complex partial seizures and their treatment. p. 331. Raven Press: New York.

DAVIDSON, D.L.W. (1983). Anticonvulsant drugs. British Medical Journal, 286, 2043.

EICHELBAUM, M., EKBOM, K., BERTILSSON, L., RINGENBERGER, V.A. \& RANE, A. (1975). Plasma kinetics of carbamazepine and its epoxide metabolite in man after
(Dalby, 1975). These beneficial effects are difficult distinguish from those resulting from withdrawal other anticonvulsants. A combination effect of $\mathrm{CB} Z$ usage and reduction in polypharmacy may operative (Thompson \& Trimble, 1982). In 2 patients (Cases 6 and 7) high plasma CBZ concentrations 9 $16 \mathrm{mg} / \mathrm{l}$ were necessary to obtain maximal benefit fro魚 the drug. Intermittent diplopia was the only adverse effect reported in this study.

Management of established partial seizures is difo ficult, with approximately $30 \%$ of patients considered to be intractable (Reynolds et al., 1983). Surgery will only benefit a select population and although recent $\overrightarrow{b 5}$ developed agents e.g. $\gamma$-vinyl GABA hold some hop for the future (Rimmer \& Richens, 1984), a ne strategy is required within the present anticonvulsam armamentarium. We feel that this report provides some limited evidence of benefit from an adequate trial of CBZ following failure with DPH or oldê agents. Although it would be desirable to identify CBZ responsive patients before withdrawal of other drugs, this has proved elusive (Rodin et al., 1974). According ly, until large scale clinical trials validate this approach, selection of patients must remain empiricas Clearly problem cases, as reported here, may be mo appropriate. CBZ therapy should not remain a negle ted alternative in patients with epilepsy poorly col trolled with polypharmacy or older agents.

\section{Acknowledgements}

Our grateful thanks go to Moira Duffy and Anne Somers fô their secretarial work in the production of this manuscrip

single and multiple doses. European Journal of Clinica Pharmacology, 8, 337.

FISCHBACHER, E. (1982). Effect of reduction of anticonvu俍. sants on well being. British Medical Journal, 285, 423. $\bar{\sigma}$

GUELEN, P.J.M., vAN DER KLEIJN, E. \& WOUDSTRA, V. (1975 Statistical analysis of pharmacokinetic parameters if epileptic patients chronically treated with anti-epileptie drugs. In Clinical Pharmacology of Anti-epileptic Drugङ p. 2. Springer-Verlag: Berlin.

GOODRIDGE, D.M.G. \& SHORVON, S.D. (1983). Epilepsy in population of 6000 . 1. Demography, diagnosis and claș. sification and the role of hospital services. 2. Treatment and prognosis. British Medical Journal, 287, 641.

KOSTELJANETZ, M., CHRISTIANSEN, J., DAM, A.M., HAN SEN, B.S., LYON, B.B., PEDERSEN, H \& DAM, M. (1979N Carbamazepine vs. phenytoin: A controlled clinical trial i⿱ focal motor and generalised epilepsy. Archives of Neurology, 36, 22.

LESSER, R.P., PIPPENGER, C.E., LUDERS, H. \& DINNER, D.\$ (1984). High dose monotherapy in treatment of intractable seizures. Neurology, 34, 707. 
MAHESHWARI, M.C. \& PADMINI, R. (1981). Role of carbamazepine in reducing polypharmacy in epilepsy. Acta Neurologica Scandinavica, 64, 22.

RAMSAY, R.E., WILDER, B.J., BERGER, J.R. \& BRUNI, J. (1983). A double blind study comparing carbamazepine with phenytoin as initial seizure therapy in adults. Neurology (Cleveland), 33, 904.

RAPEPORT, W.G., McINNES, G.T., THOMPSON, G.G., FORREST, G., PARK, B.K. \& BRODIE, M.J. (1983). Hepatic enzyme induction and leucocyte delta aminolaevulinic acid synthase activity: studies with carbamazepine. British Journal of Clinical Pharmacology, 16, 133.

REYNOLDS, E.H. (1980). Serum levels of anti-convulsant drugs: Interpretation and clinical value. Pharmacology \& Therapeutics, 8, 217.

REYNOLDS, E.H. (1975). Chronic anti-epileptic toxicity. A review. Epilepsia, 16, 319.

REYNOLDS, E.H., ELWES, R.D.C. \& SHORVON, S.D. (1983). Why does epilepsy become intractable? Lancet, ii, 952.

REYNOLDS, E.H., SHORVON, S.D., GALBRAITH, A.W., CHADWICK, D., DELLAPORTAS, C.I. \& VYDELINGUM, L. (1981). Phenytoin monotherapy for epilepsy: a long-term prospective study, assisted by serum level monitoring, in previously untreated patients. Epilepsia, 22, 475.

RIMMER, E.M. \& RICHENS, A. (1984). Double-blind study of $\gamma$-vinyl GABA in patients with refractory epilepsy. Lancet, i, 189.

RODIN, E.A., RIM, C.S. \& RENNICK, P.M. (1974). The effects of carbamazepine on patients with psychomotor epilepsy: results of a double-blind study. Epilepsia, 15, 547.

SIMONSEN, N., ZANDER OLSEN, P., KUHL, V., LUND, M. \& WENDELBOE, J. (1976). A comparative controlled study between carbamazepine and diphenylhydantoin in psychomotor epilepsy. Epilepsia, 17, 169.

SHORVON, S.D., CHADWICK, D., GALBRAITH, A.W. \& REYNOLDS, E.H. (1978). One drug for epilepsy. British Medical Journal, 1, 474.

SHORVON, S.D. \& REYNOLDS, E.H. (1979). Reduction in polypharmacy for epilepsy. British Medical Journal, 2, 1023.

THOMPSON, P.J. \& TRIMBLE, M.R. (1982). Anticonvulsant drugs and cognitive functions. Epilepsia, 23, 531.

TROUPIN, A.S. \& OJEMANN, L.M. (1975). Paradoxical intoxicaton - a complication of anti-convulsant administration. Epilepsia, 16, 753.

TROUPIN, A.S., OJEMANN, L.M., HALPERN, L., DODRILL, C., WILKUS, R., FRIEL, P. \& FEIGL, P. (1977). Carbamazepine - a double blind comparison with phenytoin. Neurology, 27, 511. 